\title{
Development and Validation of an HPLC Method for Voriconazole Active Substance in Bulk and its Pharmaceutical Formulation
}

\author{
Neslihan ÜSTÜNDAĞ OKUR, Emre Şefik ÇAĞLAR, Vildan YOZGATLI
}

\begin{abstract}
The aim of the present study was to develop and validate a High-Performance Liquid Chromatography (HPLC) method for the determination of voriconazole in drug substances and in situ gel. A mixture of acetonitrile and ultrapure water (50:50) $(\mathrm{v} / \mathrm{v})$ was used as mobile phase. The column was a C18 column (150x4.6mm with $5 \mu \mathrm{m}$ particles). The eluent was monitored with UV detection at $256 \mathrm{~nm}$ and flow rate was set to $1 \mathrm{~mL} /$ $\mathrm{min}$. The method was validated partially with respect to system
\end{abstract}

suitability, linearity, limits of detection (LOD) and quantitation (LOQ), precision, accuracy, specificity, selectivity and stability. Obtained results showed that the analytical method had good linearity, accuracy, precision, selectivity and stability. Analytical method development results indicated that the LOD was 0.022 $\mu \mathrm{g} / \mathrm{mL}$; LOQ was $0.065 \mu \mathrm{g} / \mathrm{mL}$ and assay exhibited a linear range of $1-30 \mu \mathrm{g} / \mathrm{mL}$.

Keywords: Voriconazole, HPLC, method, validation
Neslihan Üstündağ Okur, Emre Şefik Çağlar, Vildan Yozgatlı Istanbul Medipol University, School of Pharmacy, Department of Pharmaceutical Technology, Beykoz, 34810 Istanbul, Turkey

Corresponding Author: Neslihan Üstündağ Okur

Istanbul Medipol University, School of Pharmacy, Department of Pharmaceutical Technology, Beykoz, 34810, Istanbul, Turkey.

E-Posta: neslihanustundag@yahoo.com

Tel: $+902166815100 / 5190$

Fax: +0902125317555

Submitted/Gönderilme: 18.11.2015

Accepted/Kabul: 28.01.2016

Revised/Düzeltme: 25.01 .2016

\section{INTRODUCTION}

Voriconazole is chemically named as [(2R,3S)-2-(2,4difluorophenyl)-3-(5-fluoro-4-pyrimidinyl)-1-(1H-1,2,4triazol-1-yl)-2-butanol] with an empirical formula of $\mathrm{C}_{16} \mathrm{H}_{14} \mathrm{~F}_{3} \mathrm{~N}_{5} \mathrm{O}$ (Figure 1) (1) and its molecular weight is 349.3 $\mathrm{Da}$ (2). It is the Biopharmaceutics Classification System (BCS) class II antifungal drug with low aqueous solubility (3).

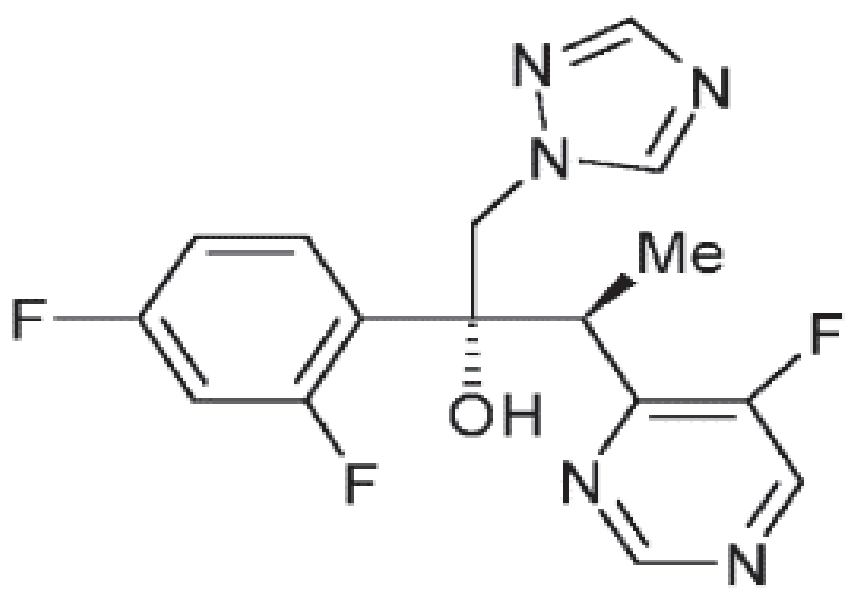

Figure 1. Chemical structure of voriconazole molecule 
Antifungal drugs carrying azole rings are the most commonly used agents in terms of treating superficial and systemic fungal infections. They work through a common mechanism of action; they selectively inhibit the synthesis of a major component of fungal cell; ergosterol and they alter the permeability of cell membrane by binding to the phospholipids of fungal cell membrane $(4,5)$. Voriconazole, a new-generation antifungal agent, possesses phenomenal characteristics like broad-spectrum activity against resistant fungal species, and acceptable tolerability. Almost 100\% in vitro susceptibility was observed against various fungal isolates associated with keratitis and endophthalmitis. Moreover, studies suggested an excellent efficacy of voriconazole against several ocular mycoses following topical administration (6).

Fungal keratitis is a leading cause of serious ocular morbidity and blindness. It shows worldwide spread, but is more common in the tropics and subtropical regions. In fungal keratitis, early diagnosis and antifungal therapy is necessary in terms of preventing further complications such as hypopyon formation, endophthalmitis, or loss of vision (7). Whilst reports on the use of $1 \%$ voriconazole eye drops in the management of ophthalmic fungal keratitis have been promising, the voriconazole concentrations achieved in the eye were not sufficiently high to treat all types of fungal keratitis (8).

Voriconazole was studied for HPLC method and validation for bulk samples and tablet dosage forms $(9,10)$. Furthermore voriconazole was determined in human plasma and serum by HPLC for application to pharmacokinetic studies of voriconazole $(11,12,13)$. Although several HPLC methods can be found in the literature for Voriconazole, to date, no HPLC methods for voriconazole determination in in situ gel formulation have been described. In the present investigation, a simple, optimized, and validated HPLC method was developed for the standardization of voriconazole. The aim of this study was to develop and validate an analytical method for voriconazole in bulk and in situ gel (containing poloxamer 188, poloxamer 407 and benzalkonium chloride), which is a novel drug delivery system for voriconazole active ingredient.

\section{EXPERIMENTAL}

\section{Materials}

HPLC grade Acetonitrile (Sigma, Germany) was used for HPLC. Voriconazole was purchased from Sigma,
USA. Poloxamer 407 and poloxamer 188 were purchased from BASF, Turkey. All the other chemicals and solvents were analytical or HPLC reagent grade. Ultrapure water was obtained from Direct-Q Water Purification System, Germany.

\section{Instrumentation}

The HPLC system consisted of a gradient pump, thermostable column department and a UV detector supplied by Agilent

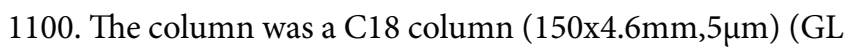
Sciences, Japan). The column compartment was temperature controlled and UV detector was employed throughout the analysis. Chromatographic data was acquired by using empower software.

\section{Chromatographic Conditions}

The voriconazole samples were analyzed using a UV spectrometer (UV-1800, Shimadzu, Japan) covering the range of 190-400 nm. The optimum wavelength selected was 256 $\mathrm{nm}$ (Figure 2), which represents the wavelength of maximum response for all impurities in order to permit simultaneous determination of related impurities of voriconazole.

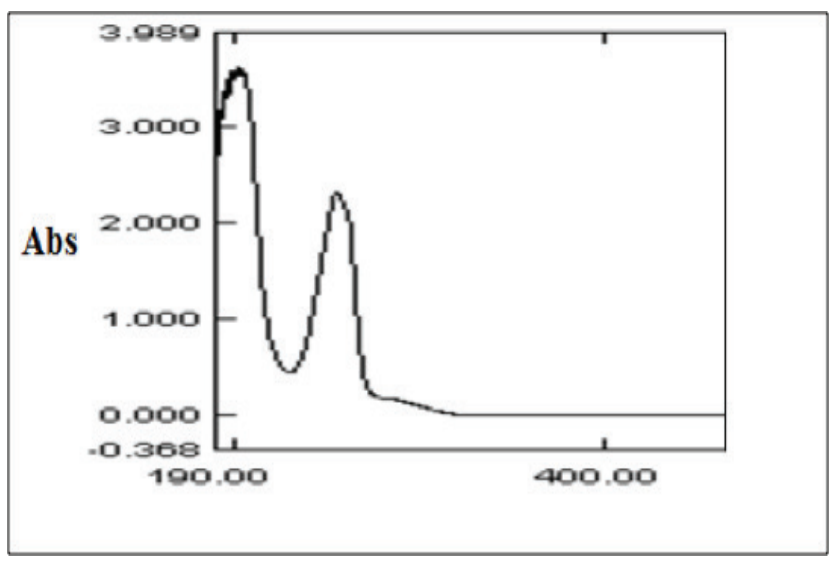

Figure 2. UV spectrum of voriconazole

The mobile phase was prepared by mixing acetonitrile and ultrapure water $(50: 50)(\mathrm{v} / \mathrm{v})$ with flow rate of $1 \mathrm{~mL} / \mathrm{min}$ (14). All solutions were filtered through a $0.45 \mu \mathrm{m}$ membrane (Sartorius, Germany) prior to use. The flow rate was $1 \mathrm{~mL} /$ min and the column temperature was maintained at $25 \pm 1$ ${ }^{\circ} \mathrm{C}$. The volume of injection was adjusted $10 \mu \mathrm{l}$. The column was equilibrated for at least $40 \mathrm{~min}$ with the mobile phase flowing through the system before the injection of the drug standards. The run time was set at $10 \mathrm{~min}$ with the system operating at air-conditioned temperature $\left(25 \pm 1^{\circ} \mathrm{C}\right)$. 


\section{Preparation of stock solutions and standard working solution}

Stock solutions of voriconazole $(100 \mu \mathrm{g} / \mathrm{mL})$ was prepared by dissolving $6.2 \mathrm{mg}$ of drug in $62 \mathrm{ml}$ mixture of acetonitrile and ultrapure water $(50: 50)(\mathrm{v} / \mathrm{v})$. The standard solutions were stored at $4 \pm 1{ }^{\circ} \mathrm{C}$ in a clear glass volumetric flask and lightprotected with aluminum foil. Voriconazole concentrations in the working solution chosen for the calibration curves were $1,3,5,8,11,14,17,20,25$ and $30 \mu \mathrm{g} / \mathrm{mL}$. Quality control (QC) samples (of low, medium and high concentration) at 8,11 and $14 \mu \mathrm{g} / \mathrm{mL}$ were prepared in the same ways as the calibration standards. These working solutions were prepared fresh daily by making further dilutions of the stock solution in mobile phase. All samples were filtered through an aqueous $0.2 \mu \mathrm{m}$ pore size membrane filter before injection.

\section{HPLC Method Validation}

The described method was validated partially with respect to system suitability, linearity, limit of detection (LOD) and quantitation (LOQ), precision, accuracy and specificity, selectivity and stability.

\section{Specificity/Selectivity}

The specificity of an analytical method is its ability to measure accurately and specifically the analyte in the presence of components that may be expected to be present in the sample matrix. To evaluate the specificity of the analytical method, the blank and drug loaded pharmaceutical formulation has been injected into the chromatographic system. These parameters were determined by comparing the chromatograms of the voriconazole standard, drug loaded in situ gel and blank in situ gel (15).

\section{Linearity}

The linearity between peak area and concentration was analyzed using calibration curve obtained from standard solutions of voriconazole ( 1 to $30 \mu \mathrm{g} / \mathrm{mL}$ ) (16). In addition the linearity was evaluated by linear regression analysis, which was calculated by the least-square regression analysis.

\section{Accuracy}

The accuracy of an analytical method is the closeness of test results obtained by the method to the true value and is defined recovery. The prepared three standard solutions (8, $11,14 \mu \mathrm{g} / \mathrm{mL}$ ) were injected five times at different levels as a test sample (17).

\section{Precision}

$8 \mu \mathrm{g} / \mathrm{mL}$ voriconazole solution and voriconazole loaded in situ gel was injected ten times in order to evaluate method precision, standard deviation (SD) and coefficient of variation (CV\%) (16). For intermediate precision study, three samples which different concentration were prepared and injected ten times. Intermediate precision is a measure of repeatability within laboratory variation. In order to evaluate the intermediate precision parameter, six different test solutions prepared by different analysts using the same drug substance sample have been analyzed by using different chromatographs and the difference of the experimental results obtained by two analysts has been calculated (18).

\section{Stability of the Solution}

A sample solution of voriconazole was prepared and analyzed initially and also at the end of the 48 hour by keeping the solution at room temperature (19).

\section{Robustness}

To determine the robustness of the developed method, experimental conditions were deliberately altered (18). The flow rate of the mobile phase was $1.0 \mathrm{~mL} / \mathrm{min}$. To study the effect of flow rate on the resolution, flow was ranged in between 0.5 to $1.5 \mathrm{~mL} / \mathrm{min}$.

\section{RESULTS AND DISCUSSION}

The UV spectrum of voriconazole in mobile phase was scanned in the region between 190 to $400 \mathrm{~nm}$. The $\lambda_{\max }$ was determined at $256 \mathrm{~nm}$ (Figure 2). In this method the retention time of voriconazole was about $4.09 \mathrm{~min}$.

The specificity and selectivity describe the capacity for each concentration of the analytical method to measure the drug in the presence of impurities, excipients, degradation products or matrix components. These parameters were determined by comparing the chromatograms of the voriconazole standard, drug loaded in situ gel and blank in situ gel.

There was no interference from the blank and also from the impurities at voriconazole peaks. The chromatogram of the voriconazole standard presented a peak in the retention time of 4.09 (Figure 3A). The chromatogram of standard solution without voriconazole is Figure $3 \mathrm{~B}$.The chromatogram of voriconazole loaded in situ gel sample (Figure 3C) showed a peak and retention time similar to voriconazole standard. 
The chromatogram of in situ gel without voriconazole is Figure 3D.
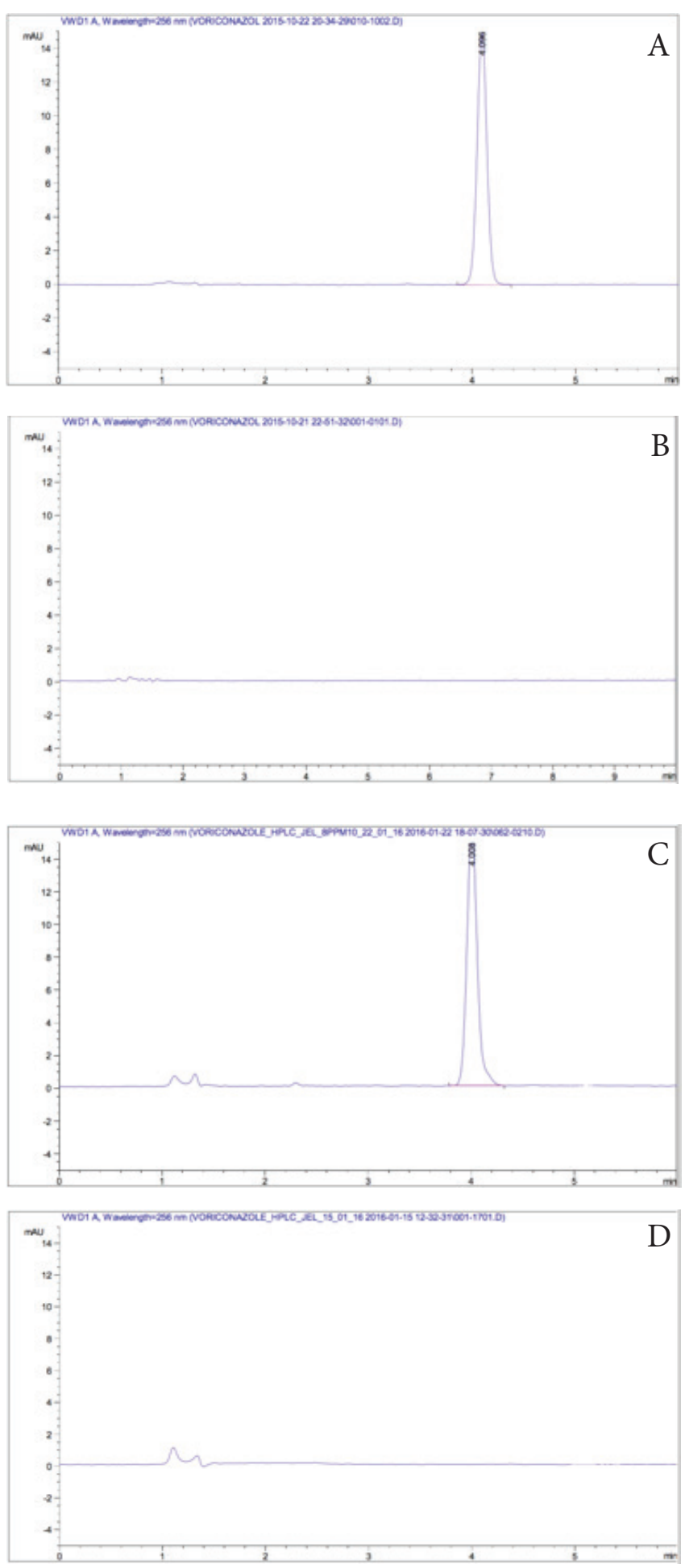

Figure 3. The chromatograms obtained in the presence (A), and absence (B) of voriconazole in standard solution, standard solution of voriconazole loaded in situ gel (C) and blank in situ gel (D). (Concentration of voriconazole $(8 \mu \mathrm{g} / \mathrm{mL})$ )
Ten points calibration graphs was constructed covering a concentration range $1-30 \mu \mathrm{g} / \mathrm{mL}$ for standard solution of bulk voriconazole. Three independent determinations were performed at each concentration. Data indicate that the voriconazole peak areas are linear over concentration range of 1 - $30 \mu \mathrm{g} / \mathrm{mL}$. Linear relationship between the peak area and concentration of voriconazole was observed. The standard deviation of the slope and intercept were low. The determination coefficient $\mathrm{R}^{2}$ for regression line is 0.999 with slope of $13.764 \mathrm{x}$ and $\mathrm{y}+$ intercept of -0.656 for standard solution of voricanozole. The analyses of calibration are shown in Figure 4.

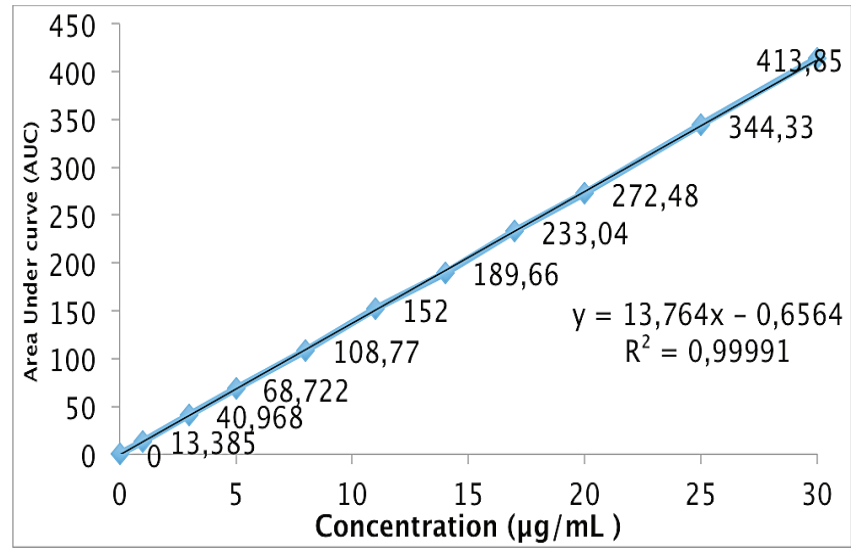

Figure 4. The regression line for voriconazole

Precision studies for an analytical procedure are being done in terms of expressing the closeness of agreement between series of measurements, which are obtained from same homogenous samples under the same conditions.

In terms of method precision study of our experiment, $8 \mu \mathrm{g} / \mathrm{mL}$ solutions were injected ten times into the system and the percentage of recovery was evaluated. As Table 1 shows, the percentage of mean recovery value was 99.09 with standard deviation of 0.29 for bulk voriconazole solution. Furthermore, the percentage of mean recovery value was 97.41 with standard deviation of 0.22 for voriconazole loaded in situ gel. Since the percentage of recovery has been found almost 100 and the standard deviation less than the acceptance criteria which is $2 \%$, the analysis system for the determination of assay is verified. Low values of standard deviation denoted very good repeatability of the measurement. Thus it was showing that the equipment used for the study was correct and hence the developed analytical method is highly repetitive. 
Table 1. The results of precision study for $8 \mu \mathrm{g} / m L$ bulk voriconazole solution and voriconazole loaded in situ gel

\begin{tabular}{ccc}
\hline $\begin{array}{c}\text { Recovery (\%) } \\
\text { test solution }\end{array}$ & $\begin{array}{c}\text { bulk voriconazole } \\
\text { solution }\end{array}$ & $\begin{array}{c}\text { voriconazole } \\
\text { loaded } \text { in situ } \\
\text { gel }\end{array}$ \\
\hline 1 & 98.89 & 97.13 \\
2 & 98.72 & 97.32 \\
3 & 98.82 & 97.32 \\
4 & 99.33 & 97.5 \\
5 & 99.26 & 97.41 \\
6 & 99.38 & 97.95 \\
7 & 99.52 & 97.41 \\
8 & 98.82 & 97.23 \\
9 & 98.97 & 97.41 \\
10 & 99.15 & 97.41 \\
Mean & 99.09 & 97.41 \\
SD & 0.29 & 0.22 \\
RSD \% & 0.29 & 0.22 \\
\hline
\end{tabular}

Intermediate precision study can be defined as measurement of repeatability within laboratory variations. In order to evaluate the intermediate precision parameter, two analysts prepared six different samples with the same concentration (Table 2).

Table 2. Intermediate precision study results $(8 \mu \mathrm{g} / \mathrm{mL})$

\begin{tabular}{ccc}
\hline $\begin{array}{c}\text { Test } \\
\text { Solution }\end{array}$ & $\begin{array}{c}\text { Voriconazole[\%] } \\
\text { Analyst 1 }\end{array}$ & $\begin{array}{c}\text { Voriconazole[\%] } \\
\text { Analyst 2 }\end{array}$ \\
\hline 1 & 109.72 & 105.45 \\
2 & 107.82 & 106.90 \\
3 & 107.89 & 107.96 \\
4 & 111.2 & 109.49 \\
5 & 108.47 & 108.99 \\
6 & 107.16 & 108.37 \\
Mean & 108.84 & 107.95 \\
SD & 1.77 & 1.37 \\
RSD \% & 1.63 & 1.27 \\
\hline
\end{tabular}

The accuracy of an analytical method is the closeness of test results obtained by that method to the true value. The accuracy of an analytical method can be defined as the ratio of obtained concentration values to true values and its percentage of recovery (20).

The mean recovery data of voriconazole in sample were within the range of 99.49 and 100.7 \%. The mean \% R.S.D. was in between 0.09 to $0.24 \%$ satisfying the acceptance criteria for the study. Hence the accuracy of the method was confirmed, this developed method can be used for further studies. Recovery (\%) of voriconazole was given in Table 3.

Table 3. Percent recovery and coefficient of variations

\begin{tabular}{|c|c|c|c|}
\hline \multicolumn{4}{|c|}{ Recovery (\%) } \\
\hline $\begin{array}{l}\text { Voriconazole } \\
\text { concentrations }\end{array}$ & $\begin{array}{c}\text { Injection } \\
\text { times of } \\
\text { test } \\
\text { solution }\end{array}$ & Bulk & $\begin{array}{c}\text { Voriconazole } \\
\text { loaded in situ } \\
\text { gel }\end{array}$ \\
\hline \multirow{8}{*}{$8 \mu \mathrm{g} / \mathrm{mL}$} & 1 & 99.66 & 97.13 \\
\hline & 2 & 99.65 & 97.32 \\
\hline & 3 & 99.64 & 97.32 \\
\hline & 4 & 99.13 & 97.5 \\
\hline & 5 & 99.38 & 97.41 \\
\hline & Mean & 99.49 & 97.33 \\
\hline & SD & 0.24 & 0.13 \\
\hline & RSD \% & 0.24 & 0.14 \\
\hline \multirow{8}{*}{$11 \mu \mathrm{g} / \mathrm{mL}$} & 1 & 100.63 & 98.32 \\
\hline & 2 & 100.43 & 98.38 \\
\hline & 3 & 100.44 & 98.19 \\
\hline & 4 & 100.42 & 97.92 \\
\hline & 5 & 100.51 & 98.19 \\
\hline & Mean & 100.49 & 98.2 \\
\hline & SD & 0.09 & 0.18 \\
\hline & RSD \% & 0.09 & 0.18 \\
\hline \multirow{8}{*}{$14 \mu \mathrm{g} / \mathrm{mL}$} & 1 & 100.83 & 98.27 \\
\hline & 2 & 100.59 & 97.75 \\
\hline & 3 & 100.48 & 97.64 \\
\hline & 4 & 100.65 & 97.38 \\
\hline & 5 & 100.94 & 97.38 \\
\hline & Mean & 100.7 & 97.69 \\
\hline & SD & 0.18 & 0.36 \\
\hline & RSD \% & 0.18 & 0.37 \\
\hline
\end{tabular}

Samples should be tested over at least a 48 hour period (depends on intended use), and quantitation of components should be determined by comparison to freshly prepared standards. The stability of voriconazole in $11 \mu \mathrm{g} / \mathrm{mL}$ standard solutions was determined by storing the solutions at ambient temperature $\left(25 \pm 1{ }^{\circ} \mathrm{C}\right)$. After two successive days of storage, the freshly prepared solution and the previous ones were injected into the system and afterwards the data were compared to each other. In each case, it could be noticed that solutions were stable for 48 hours. Furthermore, the percentage of mean recovery of freshly prepared and 48 hour old of $11 \mu \mathrm{g} / \mathrm{mL}$ solution was found 100.05 and 100.10, 
respectively. This denotes that voriconazole in stable in standard solutions for at least 2 days at ambient temperature. For $11 \mu \mathrm{g} / \mathrm{mL}$ standard solutions of voriconazole loaded in situ gel, results of percentage recovery for freshly prepared and 48 hour old solutions are shown in Table 4.

Table 4. The percentage of mean recovery of two $11 \mu \mathrm{g} / \mathrm{mL}$ solutions, which are prepared in two different days

\begin{tabular}{ccccc}
\hline & \multicolumn{2}{c}{$\begin{array}{c}\text { Bulk Voriconazole } \\
\text { solution }\end{array}$} & \multicolumn{2}{c}{$\begin{array}{c}\text { Voriconazole loaded } \\
\text { in situ gel }\end{array}$} \\
$\begin{array}{c}\text { Injection } \\
\text { times }\end{array}$ & $\begin{array}{c}\text { Recovery } \\
(\mathbf{\%}) \mathbf{0 ~ h}\end{array}$ & $\begin{array}{c}\text { Recovery } \\
(\%)\end{array}$ & $\begin{array}{c}\text { Recovery } \\
\mathbf{( \% )}\end{array}$ & $\begin{array}{c}\text { Recovery (\%) } \\
\mathbf{4 8 ~ h}\end{array}$ \\
\hline $\mathbf{1}$ & 99.91 & 99.79 & 97.13 & 100.86 \\
$\mathbf{2}$ & 100.05 & 99.87 & 97.32 & 100.86 \\
$\mathbf{3}$ & 100.00 & 100.18 & 97.32 & 100.77 \\
$\mathbf{4}$ & 100.3 & 100.14 & 97.5 & 100.95 \\
$\mathbf{5}$ & 100.02 & 100.13 & 97.41 & 100.68 \\
$\mathbf{6}$ & 100.11 & 100.4 & 97.95 & 100.77 \\
$\mathbf{7}$ & 100.02 & 100.32 & 97.41 & 101.22 \\
$\mathbf{8}$ & 99.89 & 99.92 & 97.23 & 100.95 \\
$\mathbf{9}$ & 100.08 & 99.98 & 97.41 & 100.86 \\
$\mathbf{1 0}$ & 100.15 & 100.27 & 97.41 & 101.13 \\
Mean & 100.05 & 100.10 & 97.41 & 100.9 \\
SD & 0.12 & 0.20 & 0.22 & 0.17 \\
RSD \% & 0.12 & 0.20 & 0.22 & 0.17 \\
\hline
\end{tabular}

The Limit of Detection (LOD) and Limit of Quantitation (LOQ) tests for the procedure are performed on samples containing very low concentrations of analyses. LOD is defined as the lowest amount of analyze that can be detected above baseline noise; typically, three times the noise level. LOQ is defined as the lowest amount of analyze which can be reproducibly quantitated above the baseline noise, that gives $\mathrm{S} / \mathrm{N}=10(21)$. LOD was found $0.022 \mu \mathrm{g} / \mathrm{mL}$ and LOQ was found $0.065 \mu \mathrm{g} / \mathrm{mL}$.

Vorikonazol Etken Maddesi Ve Farmasötik Formülasyonları İçin HPLC Yönteminin Geliştirilmesi Ve Validasyonu

Öz

Mevcut çalışmanın amacı, vorikonazol etkin maddesi ve farmasötik formları için yüksek performanslı sıvı kromatografisi kullanılarak bir analitik yöntemin geliştirilmesi ve validasyonunu kapsamaktadır. Mobil faz olarak asetonitril ve ultra saf su karışımı (50:50) kullanılmıştır. Analiz işlemlerinde C18 kolonu (150x4.6mm; 5 $\mu \mathrm{m}$ ) kullanılmıştır. Eluent, dakikada
To evaluate the effect of the flow rate on assay results, $11 \mu \mathrm{g} / \mathrm{mL}$ voriconazole solution was analyzed at different flow rates. Changes on the flow rate showed understandable and proportional extension over the retention time of peaks (Table 5).

Table 5. Effect of the flow rate variation on assay results

\begin{tabular}{cc}
\hline Flow rate & Retention time \\
\hline $0.5 \mathrm{~mL} / \mathrm{min}$ & 8.43 \\
$0.8 \mathrm{~mL} / \mathrm{min}$ & 5.15 \\
$1 \mathrm{~mL} / \mathrm{min}$ & 4.1 \\
$1.2 \mathrm{~mL} / \mathrm{min}$ & 3.43 \\
$1.5 \mathrm{~mL} / \mathrm{min}$ & 2.75 \\
\hline
\end{tabular}

\section{CONCLUSION}

A simple, precise, accurate, reproducible, highly sensitive and effective stability indicating HPLC method was developed and validated for simultaneous quantitative determination of voriconazole. The method was validated for accuracy, precision, specificity, and linearity. The developed method is stability indicating and it is LOD and LOQ values are in the range of $0.022 \mu \mathrm{g} / \mathrm{mL}$ and $0.065 \mu \mathrm{g} / \mathrm{mL}$ for voriconazole, respectively. In this study, the high recovery and low relative standard deviation confirm the suitability of the method for determination of voriconazole in pharmaceutical dosage forms. In conclusion, this method can be used for the routine determination of voriconazole in pure and pharmaceutical formulations.

\section{Acknowledgements}

The authors would like to acknowledge Istanbul Medipol University REMER for enabling us to use its laboratory instruments.

\section{Declaration of Interest}

The authors declare no conflict of interest.

$1 \mathrm{ml}$ ' ye ayarlanan akış hızı ve $256 \mathrm{~nm}$ dalga boyunda UV detektör yardımıyla gözlenmiştir. Yöntemin validasyon işlemleri için sırasıyla sisteme uygunluk, doğrusallık, tespit ve miktar limiti, kesinlik, özgünlük, doğruluk, seçicilik ve stabilite deneyleri yapılmıştır. Elde edilen sonuçlar, geliştirilen analitik yöntemin iyi düzeyde doğrusallığa, doğruluğa, kesinliğe, seçiciliğe ve stabiliteye sahip olduğunu göstermiştir. Analitik yöntem geliştirme sonuçları, $1-30 \mu \mathrm{g} / \mathrm{mL}$ doğrusal aralıkta, tespit sınırını $0.02176 \mu \mathrm{g} / \mathrm{mL}$ ve miktar sınırını ise $0.06528 \mu \mathrm{g} /$ $\mathrm{mL}$ olarak göstermiştir.

Anahtar kelimeler: vorikonazol, HPLC yöntem validasyonu 


\section{REFERENCES}

1. Zhoua L, Glickmanb RD, Chenb N, Sponsel WE, Graybill JR, Lam KW. Determination of voriconazole in aqueous humor by liquid chromatography-electrospray ionization-mass spectrometry. J Chromatogr B 2002; 776: 213-20.

2. Babu GS, Raju AI. UV-Spectrophotometric determination of voriconazole in bulk and its formulation. Asian J Chemistry 2007; 19: 1625-7.

3. Kumar SS, Thakuria R, Nangia A. Pharmaceutical cocrystals and a nitrate salt of voriconazole. Cryst Eng Comm 2014; 16: 4722-31.

4. Yang W, Wiederhold NP, Williams RO, 3rd. Drug delivery strategies for improved azole antifungal action. Expert Opin Drug Deliv 2008; 5: 1199-216.

5. Zhang AY, Camp WL, Elewski BE. Advances in topical and systemic antifungals. Dermatol Clin 2007; 25: 16583.

6. Kumar R, Sinha VR. Preparation and optimization of voriconazole microemulsion for ocular delivery. Colloid Surf B 2014; 117: 82-8.

7. Moemen D, Bedir T, Awad EA, Ellayeh A. Fungal keratitis: Rapid diagnosis using methylene blue stain. EJBAS 2015; 2: 289-94.

8. Al-Badriyeh D, Lok L, Roydhouse T, Li J, Daniell M, Fullinfaw RO, Davies GE, Stewart K, Kong DCM. $2 \%$ voriconazole eye drops for the management of ophthalmic fungal keratitis. IJID 2008; 12: 285.

9. Bharathi J, Sridhar B, Jitendra Kumar P, Upendra rao U, Nagaraju P, Hanumantha rao K. Validated RP-HPLC method for the estimation of voriconazole in bulk and tablet dosage form. Int J Res Pharm Biomed Sci 2010; 1: 14-8.

10. Pennick GJ, Clark M, Sutton DA, Rinaldi MG. Development and validation of a high-performance liquid chromatography assay for voriconazole. Antimicrob Agents Chemother 2003; 47, 2348-50.

11. Zhang M, Moore GA, Barclay ML, Begg EJ. A simple high-performance liquid chromatography method for simultaneous determination of three triazole antifungals in human plasma. Antimicrob Agents Chemother 2013;
57: 484-9.

12. Lin D, Li G, Chen L. Determination of voriconazole in human plasma by HPLC-ESI-MS and application to pharmacokinetic study. J Chromatogr Sci 2013;51:4859.

13. Tang PH. Quantification of antifungal drug voriconazole in serum and plasma by HPLC-UV. J Drug Metab Toxicol 2013; 4: 1-5.

14. Srinubabu G, Raju ChAI, Sarath N, Kumar PK, Rao JVLNS. Development and validation of a HPLC method for the determination of voriconazole in pharmaceutical formulation using an experimental design. Talanta 2007; 71: 1424-9.

15. Urban MCC, Mainardes RB, Gremião. Development and validation of HPLC method for analysis of gexamethasone acetate in microemulsions. Braz J Pharm Sci 2009; 45: 87-92.

16. Ramos GP, Dias PMB, Morais CB, Fröehlich PE, Agnol $\mathrm{MD}$, Zuanazzi JAS. LC determination of four isoflavone aglycones in red clover. Choromatographia 2008; 67: 125-9.

17. Shen J, Wang Y, Ping Q, Xiao Y, Huang X. Muchoadhesive effect of thiolated PEG stearte and its modified NLC for ocular drug delivery. J Control Release 2009; 137: 21723.

18. Hacıoğlu A, Çıtlak A, Karakuş S. Development and validation of an HPLC method for determination of nateglinide in drug substances. Marmara Pharm J 2015; 19: $103-8$.

19. Tippa DMR, Singh N. Development and Validation of Stability Indicating HPLC Method for Simultaneous Estimation of Amoxicillin and Clavulanic Acid in Injection. Am J Anal Chem 2010; 1: 95-101.

20. Guideline for Submitting Samples and Analytical Data for Methods Validation. FDA, February 1987.

21. Bhadra S, Das SC, Roy S, Arefeen S, Rouf ASS. Development and validation of RP-HPLC method for quantitative estimation of vinpocetine in pure and pharmaceutical dosage forms. Chromatogr Res Int 2011;ID 801656. 